\title{
The use of karst geomorphology for planning, hazard avoidance and development in Great Britain.
}

By Anthony H. Cooper*, Andrew R. Farrant and Simon J. Price

British Geological Survey, Keyworth, Nottingham, NG12 5GG.

*Corresponding author. Tel: +44 115 9363393; fax +44 1159363385

E-mail addresses: ahc@bgs.ac.uk (A.H.Cooper), arf@bgs.ac.uk (A.R.Farrant). sprice@bgs.ac.uk (S.J.Price)

Manuscript copy of paper published in Geomorphology Vol 134, pp 118-131, 2011. DOI: 10.1016/j.geomorph.2011.06.004

Please respect copyright and please consult the and quote the published version for the definitive paper which has minor changes from this manuscipt.

\begin{abstract}
Within Great Britain five main types of karstic rocks - dolomite, limestone, chalk, gypsum and salt - are present. Each presents a different type and severity of karstic geohazard which are related to the rock solubility and geological setting. Typical karstic features associated with these rocks have been databased by the British Geological Survey (BGS) with records of sinkholes, cave entrances, stream sinks, resurgences and building damage; data for more than half of the country has been gathered. BGS has manipulated digital map data, for bedrock and superficial deposits, with digital elevation slope models, superficial deposit thickness models, the karst data and expertly interpreted areas, to generate a derived dataset assessing the likelihood of subsidence due to karst collapse. This dataset is informed and verified by the karst database and marketed as part of the BGS GeoSure suite. It is currently used by environmental regulators, the insurance and construction industries, and the BGS semi-automated enquiry system. The database and derived datasets can be further combined and manipulated using GIS to provide other datasets that deal with specific problems. Sustainable drainage systems, some of which use soak-aways into the ground, are being encouraged in Great Britain, but in karst areas they can cause ground stability problems. Similarly, open loop ground source heat or cooling pump systems may induce subsidence if installed in certain types of karstic environments such as in chalk with overlying sand deposits. Groundwater abstraction also has the potential to trigger subsidence in karst areas. GIS manipulation of the karst information is allowing Great Britain to be zoned into areas suitable, or unsuitable, for such uses; it has the potential to become part of a suite of planning management tools for local and National Government to assess the long term sustainable use of the ground.
\end{abstract}

Keywords: karst; subsidence; sinkhole; hazard; drainage; GIS; planning; development; 


\section{Introduction}

Within Britain the five main soluble (or karstic) rocks - dolomite, limestone, chalk, gypsum and salt (Figure 1) - each have a different solubilities, dissolution rates and geological settings. These produce different geomorphologic environments and associated geohazards. Where these rocks occur, dissolution may induce ground subsidence, often triggered by anthropogenic disturbance, either by loading, surface water disposal or by altering the groundwater regime. Like all karstic areas significant engineering and foundation problems can be present and these pose challenges for planning and development (Fleury, 2009). These problems are, highlighted in the British Government Planning Policy Guidance PPG14 for development on unstable ground (Department of the Environment, 1990; Department of Transport Local Government and the Regions, 2002). Karst development also has implications for aquifer vulnerability and the rapid transmission of groundwater and contaminants. Consequently, aquifer protection zones for England and Wales are delineated by the Environment Agency to fulfil the Groundwater Regulations (Government Draft Statutory Instruments, 2009). These were introduced to accord with the Water Framework Directive (European Parliament, 2000) and Groundwater Directive on the Protection of Groundwater Against Pollution and Deterioration (European Parliament, 2006). To service these requirements, there is a need for a national dataset that will inform and help to manage the natural and anthropogenic pressures imposed on the the karstic rocks of Great Britain.

In this paper we consider the five types of soluble rocks in Great Britain and their different styles of karstic features. We detail the information that we gather and store in the British Geological Survey karst database and how we utilise that information. We show how new datasets showing the susceptibility to subsidence and collapse can be derived by manipulating various layers of geological information for bedrock and superficial deposits along with slope models and expert input about the karstic systems. Finally we demonstrate some of the applications of this information for engineering, planning, aquifer management, ground source heat pumps, sustainable drainage systems (SuDS), site assessment, insurance and public protection. 


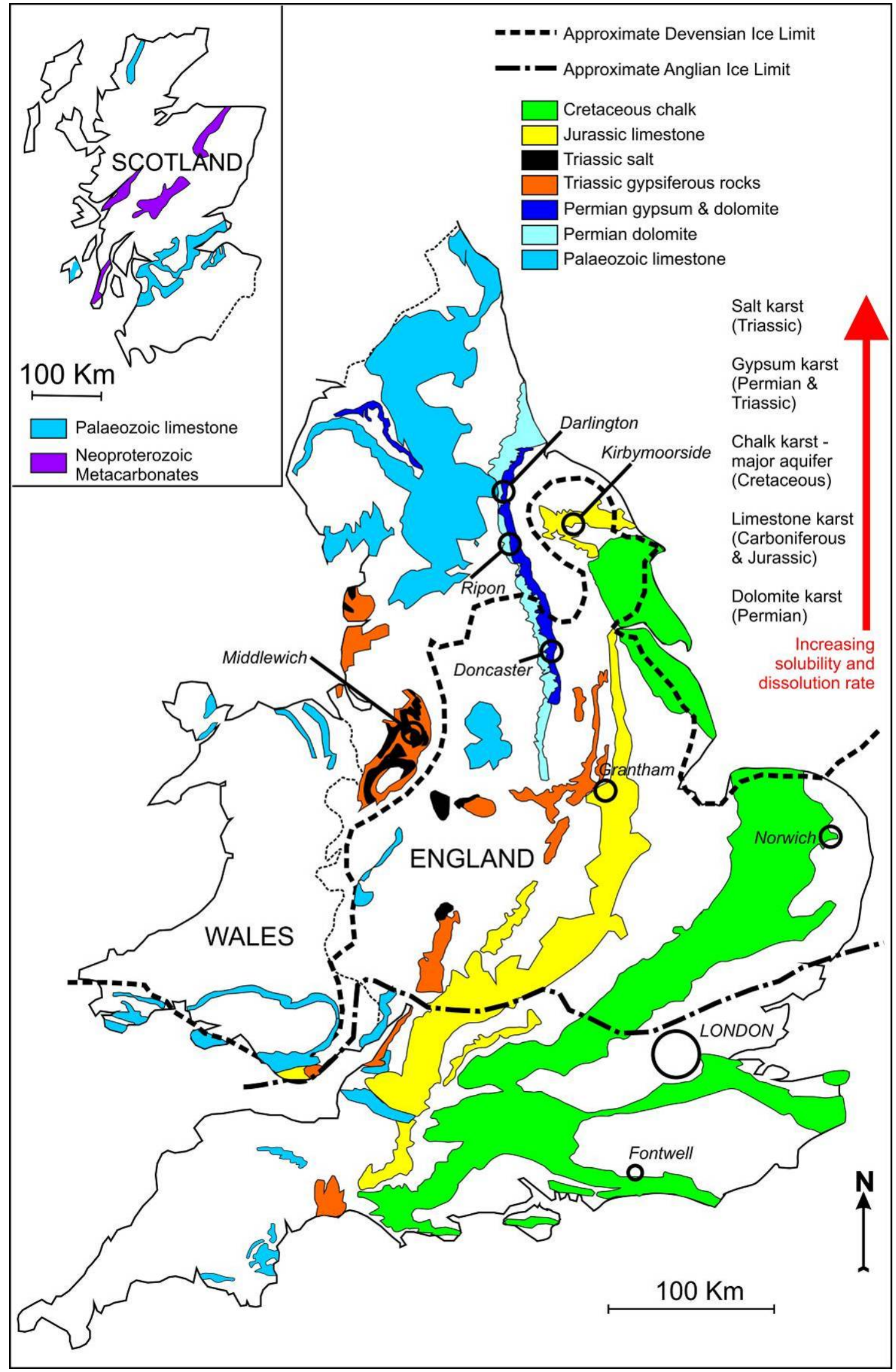

Figure 1. Soluble rock types and their distribution in the Great Britain. Based on the BGS 1:625,000 scale Bedrock Geology map of the UK, copyright BGS/NERC. 


\section{Soluble rocks and karst in Great Britain}

The distribution of the main soluble rocks in Great Britain is shown in Figure 1. Their karstification and associated geological hazards relate to several factors, the soluble rock lithology being the dominant one. The geological setting is also very important, especially the nature of the overlying and underlying units, and the present topography and hydrogeology. The past climatic history of the area also has a strong influence and the much of the British karst has been affected by glaciations, glacial and periglacial processes. Areas in the north of Great Britain have suffered several glaciations and surface karstic features have been eroded and modified forming a glaciokarst landscape (Waltham et al., 1997), while sub-glacial and marginal glacial environments have influenced subsurface karstification, especially in the gypsum of northern England (Waltham and Cooper, 1998). Areas in the south of Britain that have not been glaciated have been affected by long-term karstification, much of which has been in a periglacial environment. In addition to these factors, some areas have palaeokarst or intrastratal karst features that are buried beneath thin covering formations. Reactivation of this palaeokarst, or water movement washing material into it can result in geological hazards affecting the overlying non-karstic formations. The features of the main karstic units in the UK are noted below.

\subsection{Palaeozoic Limestones}

Limestones of Carboniferous age form most of the exposed Palaeozoic limestone in England and Wales, with the best-developed karst landscapes and the longest cave systems (Waltham et al., 1997). Karst features are widespread, particularly in the Yorkshire Dales and North Pennines with their extensive limestone pavements, caves, and resurgences; famous sites in these areas include Malham Cove, Gaping Gill and Hutton Roof Crags. The Peak District has dry deeply incised valleys such as Dove Dale and cave systems including Peak Cavern. In the south the sequence is more severely folded and the Mendip Hills and Bristol area have extensive karst including Cheddar Gorge and Wookey Hole. Karst is also well developed in the Carboniferous limestones around the margins of the South Wales coal-field with the well known cave systems of Dan-yr-Ogof and Porth-yr-Ogof. Karst is also developed in Cambrian limestones and dolostones in Scotland and in Devonian limestones in south-west England (Waltham et al., 1997). Karst features in all these areas include numerous caves, stream sinks, resurgences, sinkholes and limestone pavements. Most types of sinkhole occur including solution, collapse/bedrock collapse, caprock, dropout/cover collapse, suffusion and buried sinkholes (Gutiérrez et al., 2008; Waltham et al., 2005). The major problems associated with these karst areas are mainly water supply protection, engineering problems and geological conservation. Subsidence associated with natural sinkhole formation does commonly occur. However, the majority form in remote and rural areas, but some examples have been recorded in urban areas where broken pipes and poor drainage have caused subsidence. In rural areas the subsidence hollows often become sites for illegal tipping of farm and other refuse or waste which can cause rapid contamination of the groundwater and local drinking supplies. 


\subsection{Permian Dolomite}

Permian dolomite is present, mainly in north-east England (Figure 1) (Smith, 1989), but because of its lower solubility and geomorphological setting, apart from dry valleys and a few minor caves, few karstic features have been recorded (Murphy, 2000). The exception is where the upper part of the sequence (Brotherton Formation) is underlain by gypsum and extensive interstratal karst has developed (Cooper, 1998); this is described below. Minor caves are present in the dolomite of the Cadeby, Ford and Raisby formations and in places these have caused problems for development in the areas around Sunderland and Wetherby.

\subsection{Cretaceous Chalk}

The Chalk is the most widespread carbonate rock and a major aquifer in England. Karst features include extensive dry valleys, permanent and seasonal springs, solution, dropout/cover collapse and suffusion sinkholes, with buried sinkholes in some glaciated and fluvial areas (Gutiérrez et al., 2008; Waltham et al., 2005). In places, the development of solutionally enlarged fissures and conduits can potentially cause problems for groundwater supply by creating rapid contaminant pathways though the aquifer, especially in areas adjacent to impermeable Palaeogene strata (Banks et al., 1995; Price et al., 1992). This is particularly important as the Chalk often underlies major transport corridors and several large urban areas. Chalk dissolution also generates subsidence hazards and difficult engineering conditions (Edmonds, 1983; Edmonds, 2001a; Edmonds, 2001b; Edmonds, 2008; Farrant, 2001; McDowell, 2005; McDowell et al., 2008) Problems include metastable cavities, irregular rockhead associated with the development of clay filled pipes and fissures, localised subsidence, increased compressibility and diminished rock mass quality. In the north of England (Yorkshire through to Lincolnshire) the Chalk is relatively hard and part of the area has been stripped by several glaciations removing many of the surface karstic features. There are well-developed dry valleys (Waltham et al., 1997) and major karstic springs are present, especially from the base of the Chalk along the western side of the outcrop and as submarine springs (Hessle Whelps and Barton Bulldogs) in the Humber Estuary; sinkholes, however, are uncommon in the north.

In the south of England the Chalk is generally softer than in the north. Where the Chalk crops out south of the Devensian and Anglian ice-limits it has suffered far longer exposure to surface and near-surface dissolution. Moreover, the presence of overlying Palaeogene rocks provides catchment areas for allogenic drainage onto the Chalk outcrop. Consequently, sinkholes and karstic features are far more widespread than in the north. Dry valleys predominate with seasonal winter streams (winterbournes) along with permanent and seasonal springs (Farrant, 2001). Stream sinks are common around the margins of the Palaeogene strata. In some areas, particularly south of the Anglian ice-limit the Chalk has been exposed to karstic weathering for over half a million years. One such area is the Sussex coastal plain, where despite being buried by pre-Anglian raised beach deposits and Devensian solifluction deposits, the Chalk still undergoes active dissolution at rock-head (McDowell, 2005). The result is a very subsidence-prone area where collapses can be easily triggered by 
intense rainfall events and leaking pipes, such as that which occurred at Fontwell in West Sussex (Figure 2).

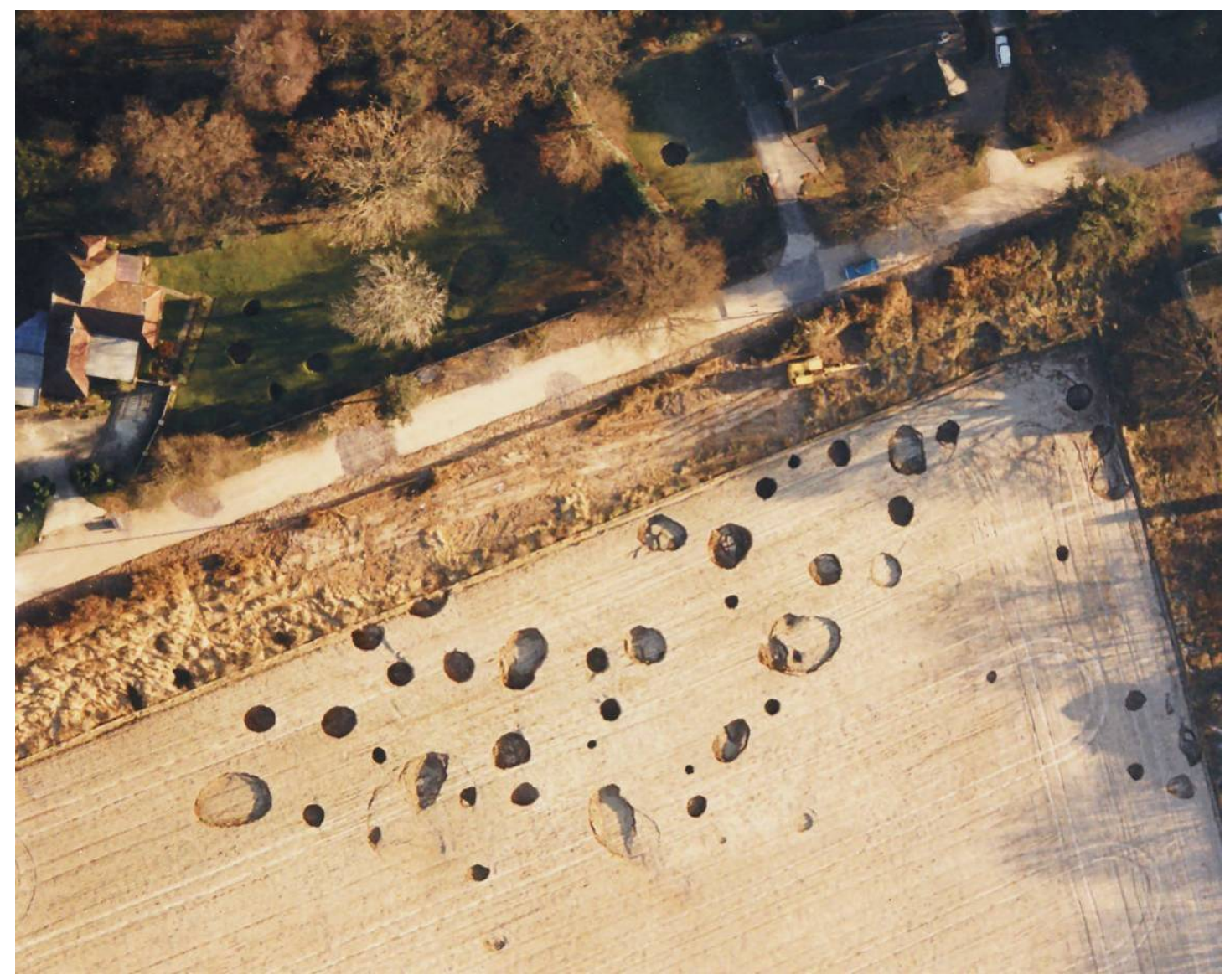

Figure 2. Seventy catastrophic dropout sinkholes caused in 1985 by a burst water main in solifluction deposits over raised beach deposits on Chalk at Littleheath Road, Fontwell, Sussex (photo @ Sealand Aerial Photography Ltd, Chichester, reproduced under licence.)

There are widespread areas in southern and eastern England where the Chalk has been previously exposed and palaeokarst is present now overlain by younger deposits.

Palaeokarst occurs widely in southern England at the Chalk-Palaeogene unconformity where it is overlain by the Reading and Thanet Sand Formations. Palaeokarst features also occur around Norwich where the Eocene Crag Group overlies the Chalk. Where these overlying deposits are permeable, karstification may continue, leading to the formation of subsidence sinkholes. In Norwich subsidence sinkholes have caused problems, sometimes compounded by mining induced subsidence (Howard Humphreys and Partners Ltd, 1993). In Kent and around the Thames estuary, the Chalk is overlain by the permeable Thanet Sand, resulting in subsidence affecting the covering deposits (Ellison, 2004; McDowell et al., 2008). 


\subsection{Jurassic Limestones.}

Limestones of Jurassic age crop out in a wide belt extending from the Dorset coast, up through the Cotswold Hills to the North York Moors (Figure 1). Although generally the limestones are thinly bedded and not particularly karstic, significant karst does occur locally, particularly in the Lincolnshire Limestone between Grantham and Stamford, and in Corallian limestones along the southern edge of the North York Moors near Kirkbymoorside.

\subsection{Permian and Triassic Gypsum}

Gypsum karst is present mainly in a belt $3 \mathrm{~km}$ wide and about $100 \mathrm{~km}$ long in the Permian rocks of eastern and north-eastern England (Figure 1) (Cooper, 1986; Cooper, 1989; Cooper, 1998). It also locally occurs in the Triassic strata (Cooper and Saunders, 2002), but the effects of it are much less severe than those in the Permian Zechstein Group rocks. This difference is mainly due to the thickness of gypsum in the Permian sequence and the fact that it has interbedded dolomite aquifers that feed water under artesian pressure through the gypsum. In contrast the Triassic gypsum is present mainly in weakly permeable mudstone sequences. The gypsum karst in the Permian sequence has formed phreatic joint-controlled cave systems (Cooper, 1986), and the rapid solubility rate of the gypsum (James, 1992; James et al., 1981; Klimchouk, 1996; Klimchouk et al., 1996) means that the karst is evolving on a human time scale. Active subsidence occurs in many places, especially around the town of Ripon. The active nature of the dissolution and the ongoing subsidence features, cause difficult conditions for planning and development. Over the Permian gypsum sinkhole formation is predominantly of the dropout/cover collapse type, but bedrock collapse and caprock collapse sinkhole types also occur (Gutiérrez et al., 2008; Waltham et al., 2005). The caprock collapse sinkholes result in enclosed cylindrical collapses up to $20 \mathrm{~m}$ deep perforating into the bedrock. Where superficial deposits are present the sinkholes start with a cylindrical (dropout or cover collapse) form, but the margins quickly fail resulting in the formation of conical depressions (Figure 3). Sinkholes filled with peat and soft clay are also common while some are filled with sulfate-rich upwelling groundwater. 


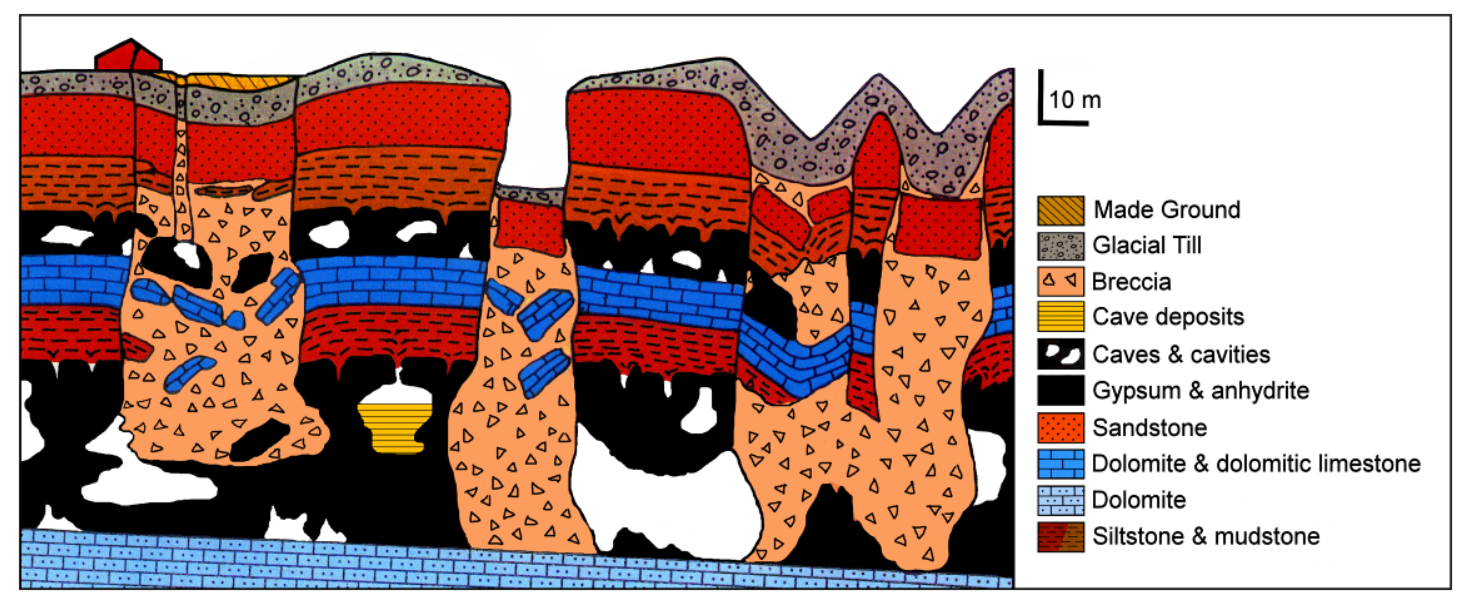

Figure 3. Schematic cross section through the Permian gypsum sequence of north-east England showing the development of caves, collapse breccia pipes and some sinkhole types in the gypsum karst.

\subsection{Permian and Triassic Salt}

Salt in Great Britain occurs mainly in the Permian and Triassic strata of central and north-eastern England (Figure 1). Many towns on the Triassic strata have "wich" or "wych" in their names indicating that they are sited on former salt springs emanating from actively dissolving salt karst (Cooper, 2002). These places, including Northwich, Middlewich and Droitwich, became the focus for shallow mining and near-surface "wild" brine extraction, a technique that exacerbated the salt karstification. In some of these areas subsidence is still occurring. Extraction of natural brine has ceased, though the linear subsidence depressions leading to the salt works are very evident (Figure 4)(Cooper, 2002; Waltham et al., 1997) Modern exploitation is in dry mines or by deep controlled brine extraction leaving brine-filled cavities. Since the cessation of natural brine pumping, the saline ground water levels have returned towards their prepumping state. Brine springs are becoming re-established and natural karstification and subsidence may be expected to occur. The exact nature of the brine flow, and how it might interact with mined and brined areas, has yet to be studied and determined.

Noted above, the various soluble lithological and stratigraphical units susceptible to karstification manifest themselves in common feature types. These include sinkholes, caves, stream sinks, resurgences and springs - all features about which national information is being collected by the British Geological Survey Karst Database. 


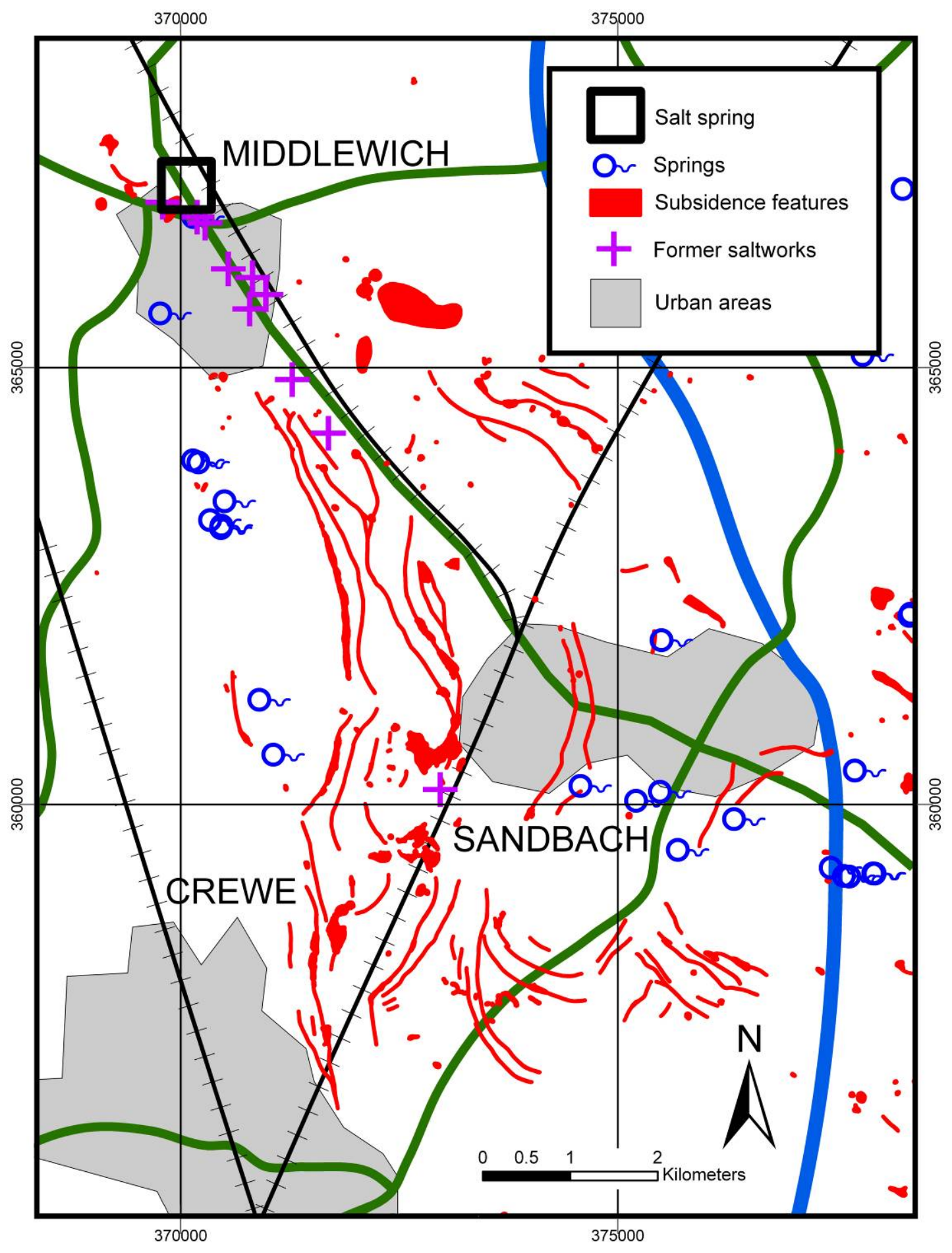

Figure 4. Salt karst subsidence features of mid Cheshire caused both naturally and induced by dissolution related to brine extraction. National Grid $($ ) Ordnance Survey, used under licence number 100017897/2010 


\section{The British Geological Survey National Karst Database}

The British Geological Survey is compiling a national database of karst features that currently includes information for about half the country (Cooper et al., 2001; Farrant and Cooper, 2008). This dataset was founded on, and has improved on information that was initially gathered for a database of natural cavities compiled for the British Government (Applied Geology Limited, 1993; Edmonds et al., 1989). Data are collected on the major karstic features including sinkholes (dolines), caves, stream sinks, springs and instances of building damage either as attributed point or polygon information. The database fields for each of these entities are listed by Farrant and Cooper (2008) and include dimensions, dates of subsidence and indications of water flows. The mapping of building damage is particularly sensitive for recording even small amounts of subsidence (Gutiérrez and Cooper, 2002) and the full building damage classification is reviewed and presented by Cooper (2008a). The use of GIS software to collect data means it can be customised for office use or for field use using ruggedized tablet computers which BGS has introduced for field surveying (Hall et al., 2010).

The data held by BGS are augmented by additional datasets held by caving clubs and Cave Registry groups. Such local societies are increasingly making data available via the web, for example the Mendip Cave Registry and Archive website (www.mcra.org.uk). Other datasets also exist and the original Applied Geology Limited database has been maintained by Peter Brett Associates as an independent commercial venture.

The factual data contained in these databases are used to inform the generation of the geological hazard assessment datasets discussed below. As more information is added to the BGS karst database it also acts as a quality control check on the derived GeoSure soluble rock dataset, the generation of which is described below.

\section{Generating geological hazard assessment datasets for soluble rocks}

BGS produces six derived map layers for geohazard susceptibility in Great Britain: landslides, compressible ground, shrink-swell clays, running sands, collapsible ground (loess etc) and soluble rocks (Harrison and Forster, 2006). Marketed as "GeoSure”, the datasets are used in products such as house stability reports and by insurance companies to limit their local exposure to geological hazards. More recently some of the information has been utilised by organisation such as the Environment Agency to help with planning and the environmental protection of karst aquifers. The dataset has also proved itself useful for the assessment of linear routes for roads and pipelines (Gibson et al., 2005).

The soluble rocks layer for GeoSure has been produced using digital geological map and other datasets including:

- Stratigraphical name and lithology for bedrock

- Stratigraphical name and lithology for the superficial cover

- $\quad$ Superficial deposit thickness

- Superficial deposits permeability 
- Slope angle from the digital terrain model

- Information from the karst database

- Expert knowledge about marginal areas and interstratal karst.

The different solubilities and geological situations require different algorithms to assess the geohazards for the different rock types. In certain situations expert polygons have been digitised to cope with situations that cannot be derived from the basic geological map information, these include interstratal karst and marginal areas affected by runoff drainage. For the main limestone and chalk units with their overlying superficial deposits a scoring scheme has been developed (Farrant and Cooper, 2008). Each contributing factor influences the type, style and degree of karstification, their relative contributions are assessed and scored accordingly. For the gypsum and salt areas where the deposits are largely buried beneath thick superficial deposits the bedrock geology and karst database (to assess the concentration of sinkholes) has been used (Cooper, 2008b). The manipulation of the numerous digital layers has been undertaken using ArcGIS and the final results are 5 subdivisions of susceptibility to the presence of karst features or problems arising from them. The ranking is from 1 to 5 , where 1 is low susceptibility and 5 is very high. The inputs into the assessment and their influence on the geohazard assessment are described below:

\subsection{BGS digital map data}

Digital map data at 1:50,000 scale are available for most of Great Britain under the banner of DiGMapGB-50. Four datasets have been gathered: bedrock geology (including faults, mineral veins, coal seams etc), superficial deposits geology, mass movement deposits (mainly landslides) and artificial deposits (mainly made ground and excavations). In addition, the geology of a significant area of the country, especially urban areas, has been digitised at the 1:10,000 scale dataset (DiGMapGB10), the scale at which most surveying has been undertaken. For this digital information each map polygon is attributed with a 2-part seed indicating the lithology and the stratigraphy. Details of both the BGS Rock Classification Scheme and the Stratigraphical Lexicon are available on the BGS website (British Geological Survey, 2010b)

\subsubsection{Bedrock geology}

A major factor in the degree of karstification is the rock type. Basic information about rock type in the digital map data is contained in the polygon seeds for lithology (detailed above). The stratigraphical units more susceptible to karst development can be identified from information contained within the karst database, literature, cave registries and local knowledge. These can then be selected using the lithological or combined lithological and stratigraphical codes, and then ranked and scored for their susceptibility to karstification and sinkhole formation.

\subsubsection{Superficial deposit geology}

The superficial deposits and their geological history have a strong influence on the susceptibility of areas to sinkhole formation. Some superficial deposits, such as highlevel river terraces and residual weathering deposits are particularly prone to collapse 
and given a high score. In many areas, such as the Chalk of southern England, the overlying materials also have a strong influence on the number of cavities and sinkholes that can develop by concentrating recharge and enabling the formation of subsidence sinkholes. Impervious capping materials concentrate runoff around their margins and these marginal areas are more prone to sinkhole formation. Permeable capping materials such as superficial sands and gravels can span cavities caused by dissolution at the interface between the superficial materials and the underlying soluble rock, but these covering materials can fail dramatically if large amounts of water are introduced. Like the bedrock, the superficial deposits are coded with a twopart attribution for the lithology and stratigraphy so the largely impervious, or mainly pervious, capping materials can be identified; this selection is informed by the BGS Superficial Permeability database. Utilising their geological settings, the deposits can be grouped together into domains and given scores dependent on their susceptibility to sinkhole (doline) development.

The role the superficial deposits have on karstification is also influenced by the thickness of the superficial deposit, their age (and thus the time available for karstification) and permeability. Models of superficial thickness for the whole country have been generated using borehole information in the BGS archives

(British Geological Survey, 2010a). This enables areas where very thick deposits protect the underlying soluble rocks from further dissolution to be identified. For example, areas of Chalk covered by 30 metres or more of glacial till are scored negatively, reducing their dissolution score. Similarly, the BGS superficial permeability database enables very permeable deposits to be identified which are more prone to dissolution at rock-head. The age of the superficial deposits is obtained from the stratigraphic lexicon, and can also be scored.

\subsection{Digital Terrain Model and slope model}

The exposed or near surface slope angle of chalk and limestone rocks influences their susceptibility to sinkhole development. Steep slopes allow the water to run off and reduce the severity of the dissolution; furthermore, rates of surface erosion may be greater than the dissolution rate. Conversely, flattish areas can develop karstic depressions at surface or beneath thin covering deposits. The British Geological Survey uses slope information from the NextMap ${ }^{\text {TM} B r i t a i n ~ e l e v a t i o n ~ d a t a ~ f r o m ~}$ Intermap Technologies to calculate this factor. The slope angle gives another score that contributes to the resultant geohazard marking.

\subsection{Expert GIS polygons}

The digital geological polygons allow the soluble rocks at the surface to be identified, but they do not cater for marginal, feather edge, interstratal effects or palaeokarst. Marginal effects occur where external drainage from an adjacent non-karstic rock flows onto a soluble rock (also known as contact karst). This can be broken down into two zones; the runoff margin and the feather edge (Figure 4). The runoff margin zone occurs where an aquitard, such as a mudstone, overlies or abuts a soluble rock such as a limestone (Figure 5). Here drainage from the impervious strata may be directed onto the adjacent limestone producing a zone of preferential limestone dissolution (Figure 6) where karst features including stream sinks, sinkholes and caves are particularly common. A feather-edge margin occurs where the aquitards are thin allowing water 
to flow into the underlying soluble rock. Here karstic features including cover collapse sinkholes and stream sinks can form in the overlying material. Depending on the lithology and fracture characteristics of the overlying material, these sinkholes can penetrate several tens of metres of cover rocks. These areas can only be identified manually or from the distribution of sinkholes shown by the karst database. Where such situations are identified, the increasing cover thickness away from the feather edge of the deposits tends to limit the karstification. The only way to gather these zones is by expert knowledge and manual digitisation. Both the runoff margin and feather edge areas are given scores that contribute to the dissolution susceptibility algorithm. Interstratal karst occurs where the karstic rocks pass beneath or are interlayered with non-karstic rocks. In this situation, for example, sandstone sequences overlying limestones or gypsum, the insoluble rocks may themselves be susceptible to sinkhole formation caused by collapse of the soluble rocks at depth (Figure 3 and Figure 5). This susceptibility and the extent of the area affected can only be determined manually and like the feather edge situation is informed by the distribution of sinkholes recorded in the karst database (Farrant and Cooper, 2008). Palaeokarst situations exist where relatively thin insoluble or poorly soluble sequences overly former erosion or land surfaces cut into soluble rocks. These situations affect strata overlying the Chalk in several places. These areas are concealed beneath non-karstic rocks and can only be included by manually identifying their extent and giving them an appropriate score.

\subsection{Calculating the sinkhole susceptibility rating}

The scoring system allows the various positive and negative factors to be identified and related to the digital map layers and expert polygons (Farrant and Cooper, 2008) . The scores can then be summed to give an overall rating of susceptibility to sinkhole formation. This model can then be verified by the data included in the karst database (Farrant and Cooper, 2008).

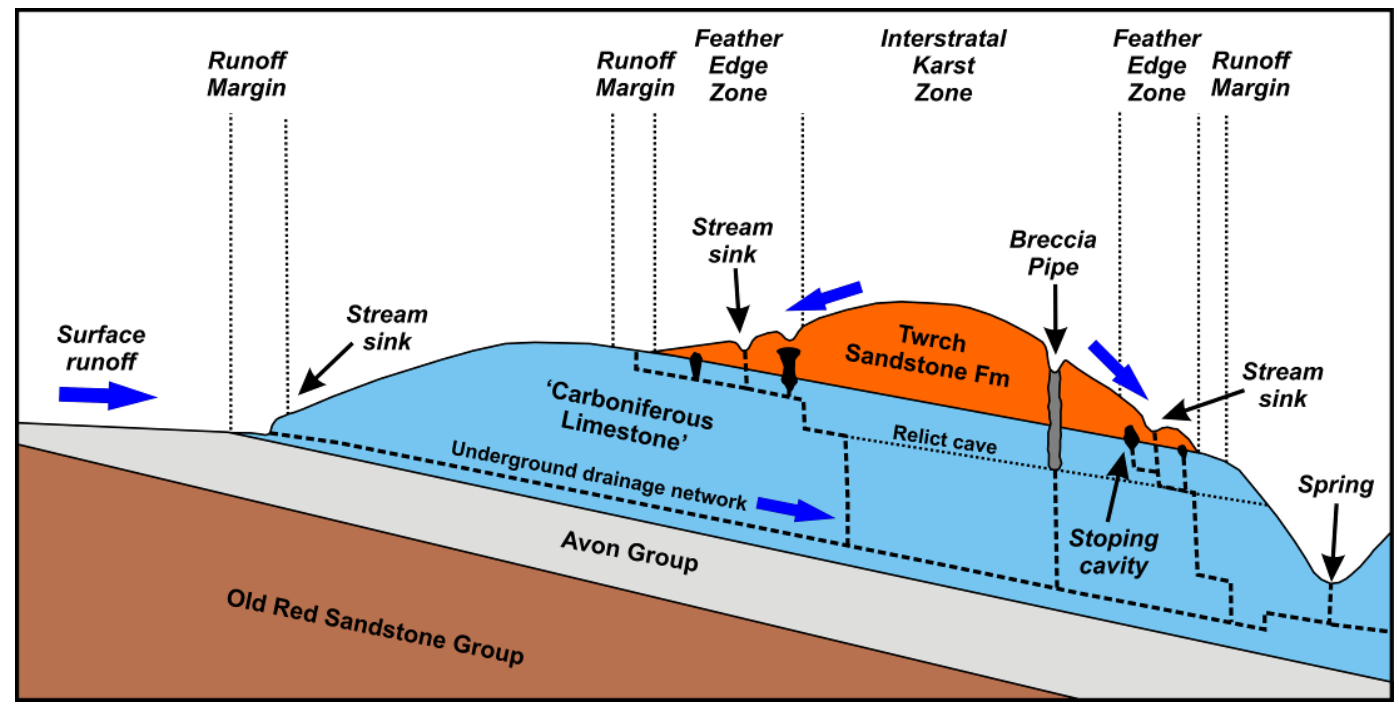

Figure 5. Schematic section through the north crop of the South Wales coalfield showing the relationships between the runoff margin, feather edge zone and Interstratal karst zone. 


\subsection{Limitations of the sinkhole susceptibility modelling}

The challenge has been to produce a National dataset covering the soluble rocks of the whole country. The methodology used is largely heuristic, but where information is available it has been calibrated against sinkhole density models derived from the karst database. A similar approach has been used by Edmonds incorporating information about subsidence events with domains based on local geology and topography (Edmonds, 2001a; Edmonds, 2001b; Edmonds et al., 1987). The heuristic approach has been questioned by some authors including Galve et al., (2009) who demonstrate that statistical methods are more accurate, but these methods only work where there are good data about the all of the sinkholes. Even where there is good spatial information about the sinkholes, morphometric analysis of old and new sinkhole densities shows that there is not always a perfect correlation (Brinkmann et al., 2008) due to the evolution of the karst and its hydrogeology. There are also areas such as Ripon (Figure 7) where there are some susceptible areas apparently without sinkholes; these comprise urban areas and flood plains in which the sinkholes readily get filled in and thus do not show on the karst database sinkhole inventory.

\subsection{Evolution of the modeled dataset}

The calculated model is not static as it changes when revised geological map information is added to the corporate collections. It is also updated if a mismatch is found between the calculated susceptibility figures and any newly input karst database information. The anomalies are examined and additional geological data such as boreholes interrogated to improve the model. This may result in changes to the scores given to the bedrock units or superficial cover. Alternatively, it may require the digitization of further marginal area/feather edge geology polygons to include in the calculated model. The finished susceptibility model has many uses including planning, construction and aquifer protection. 


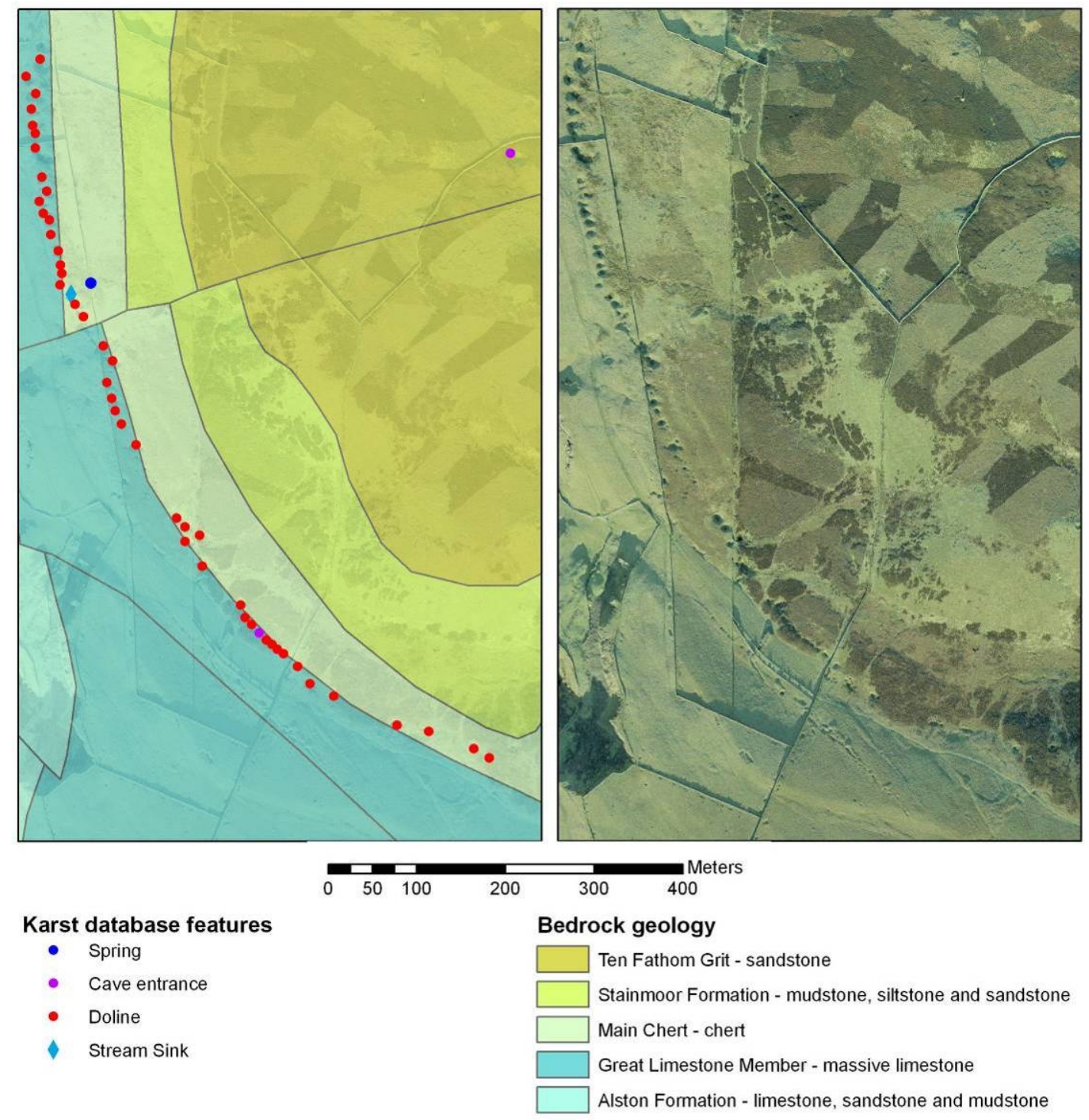

Figure 6. Sinkholes formed in the marginal runoff area where water from sandstones and mudstones sinks into limestones $2 \mathrm{~km}$ NW of Muker, North Yorkshire. Air photography (C) UKP/Getmapping reproduced under Licence No. UKP2006/01; Bedrock geology from BGS DiGMapGB-50. 


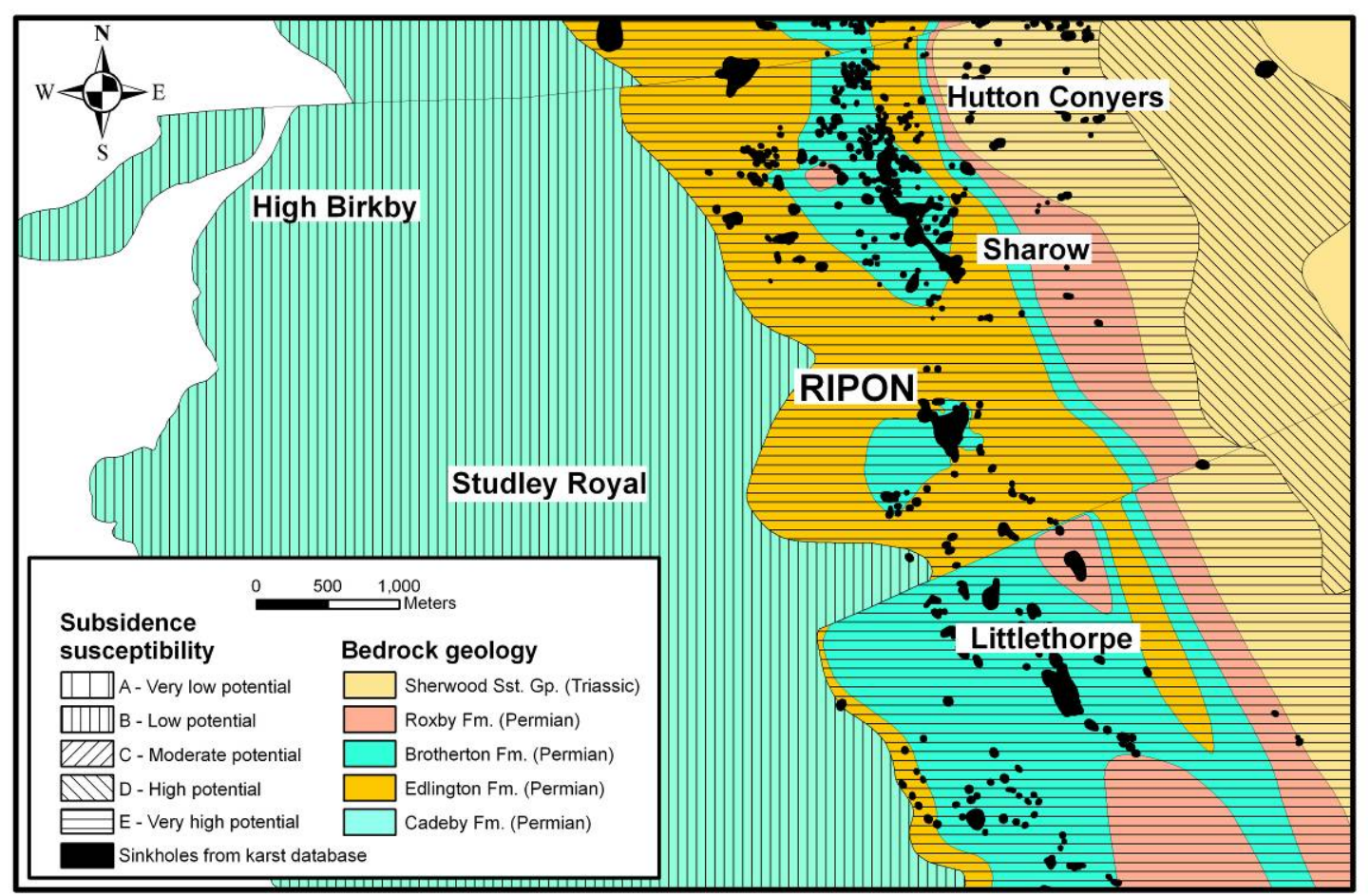

Figure 7 Comparison of GeoSure classified areas with sinkhole distribution from the karst database for the Ripon district. The main subsidence area is underlain by gypsum, the area with low potential for subsidence is underlain by dolomite. Geology from BGS 1;50,000 scale DigMap50 bedrock geology dataset copyright BGS/NERC.

\section{Planning for karst Geohazards}

Development on karstic rocks can be affected by natural subsidence, but the karst itself can be affected by subsidence caused by anthropogenic effects such as inappropriate drainage. It is well-documented that the redirection of storm runoff can lead to sinkhole development and pollution of karstic aquifers (Fleury, 2009). This is a major constraint that is considered in many sinkhole-prone areas. However, as Fleury points out, many counties and states in the USA - even adjacent ones - have very different regulations and there is no definitive consensus on what is required. Within Great Britain there are only a few places where karst problems are even considered and where regulations are in place. Planning policy guidance notes are given (referred to below), but there is little mention of mitigation measures for construction such as those described by Sowers (1996). Within Great Britain, the protection of karstic rocks susceptible to pollution from inappropriate surface drainage has been hampered by lack of public information. Information is now available as the GeoSure soluble rocks dataset, but the challenge is to get it utilized by councils and regulatory authoritories who could utilise it. The dataset gives a strong indication of the susceptibility of karstic aquifers not only to subsidence, but also to the rapidity of infiltration and as such it is a powerful tool for aquifer protection. The recent "green" desire for using ground source heat pumps has also highlighted the susceptibility of karstic aquifers to pollution and subsidence from open loop heat pump installations. The GeoSure data are potentially useful for helping to determine the suitability of areas for ground source heat pumps. The identification of areas prone to subsidence is also important for linear infrastructures such as roads, railways and pipelines, the GeoSure data help with the identification of areas where problems may occur thus helping mitigate potential problems. Finally, the dataset also helps to 
identify areas where insurance companies may wish to know more about the local hazards, both as verification of claim types and as a way of limiting their exposure to any one particular hazard.

\subsection{Local development and hazard avoidance}

The problem of soluble rocks and subsidence has been recognized by the British Government since 1990 when the first planning guidance policy document PPG 14, dealing with unstable land, was published (Department of the Environment, 1990). and the first karst database was established (Applied Geology Limited, 1993). The planning guidance document was updated in 2002

(Department of Transport Local Government and the Regions, 2002) and forms the foundation for local councils to work with. While the guidance gives information on the types of hazard and in some instances how to deal with them, it only includes a small summary map showing where karst problems may occur and some contact details for further information. Local authorities that have encountered problems of karstic subsidence are likely to include some statement about them in their local development plans, but many councils remain unaware that they have potential problems in their area and do not have the specialist skills to interpret the geological information that could help them. There are exceptions to the rule and Ripon, the worst area for gypsum dissolution, had a Government-funded study resulting in a formal planning process to help mitigate gypsum dissolution problems (Paukstys et al., 1999; Thompson et al., 1996; Thompson et al., 1998). To aid planners and developers BGS has released the GeoSure soluble rocks dataset in GIS format. This provides an easily usable summary of the likelihood of karst-related subsidence problems in a particular area. Categories of susceptibility can be matched to planning policy guidance to help manage areas affected by soluble rocks. Used together, the planning guidance, the soluble rock geological hazard data and local studies of hydrogeology and subsidence (Lamont-Black et al., 2002; Thompson et al., 1996) can be combined to constrain planning and inform safe development. To obtain the geological information planners and developers can purchase BGS site assessment reports. These are partly automated with local maps and assessments derived from numerous databases, the digital geological maps and the karst geohazard GeoSure data, plus manual descriptions and information from the karst database.

\subsection{Construction on karst areas}

In addition to careful planning and the avoidance of the most subsidence-prone areas, further protection can be afforded by local regulations and building control measures, which can include advice on ground investigation and mitigation. The starting point for any development must be a desk study of existing information including boreholes, geological and topographical maps, scientific papers and local details. The GeoSure soluble rocks information, combined with details from the karst database, can give an indication of areas where ground conditions are likely to have karstic hazards and be problematic for construction. In some well-studied areas this will provide enough information to proceed to detailed ground investigation. However, where the base information is old, geomorphological mapping of karst features allied with detailed geological mapping is the first step in understanding the site conditions. In some areas, local caving clubs and Cave Registries may hold information. Where 
karst information is not available air photograph and digital terrain model information can be utilized to understand the local distribution of karst features (Cooper, 1989).

Site investigation boreholes are commonly used to investigate ground conditions, but in karst areas they can easily miss cavities, uneven rockhead and potentially unstable ground. Microgravity geophysics has proven effective in delineating karst features (Patterson et al., 1995; Tuckwell et al., 2008); when used to inform the location of boreholes (to probe both anomalous and background areas) it can dramatically reduce drilling costs while improving the knowledge of the spatial distribution of the anomalous ground. Resistivity tomography is less labour-intensive than microgravity and has proved similarly effective on sites that have not been previously developed. Combining techniques such as ground probing radar with resistivity tomography and trenching can give a much fuller picture (Gutiérrez et al., 2009). Shallow seismic has shown promise (Sargent and Goulty, 2009), but is the most labour-intensive of the 3 techniques and hence costly.

Measures used to mitigate ground instability in karstic areas include reinforced foundations including rafts, slabs, reinforced strips and piles (Sowers, 1996; Thompson et al., 1996; Waltham et al., 2005). Piles can be effective in areas of uneven rockhead, but in areas of thick superficial cover over the bedrock, they may not be practical and strengthened foundations such as rafts are preferable. If a ground collapse occurs beneath a corner of a raft, and depending on the design specification, there is a possibility that the building may cantilever over the hole or the corner may fail. To prevent this, further support for the structure can be afforded by adding extension beams that project outwards from the foundation to span any potential collapse (Cooper and Calow, 1998; Reuter et al., 1990). Of major importance in karst areas is the integrity of the water supply and drainage systems. Leaking water can in many places trigger catastrophic subsidence; as a result, flexible connections and resilient pipework are important in this type of terrain. Further protection can be added by using waterproof membranes in service trenches so that any leakage is carried away from the buildings and drained harmlessly away.

Road and bridge construction in active karst areas should also accommodate potential problems through mitigation. Around Ripon a new road has been protected with geogrid materials while a strengthened bridge capable of losing any one of its supports without collapsing spans the river(Cooper and Saunders, 2002). Over Triassic gypsum karst near Derby a reinforced road construction techniques have been utilized (Cooper and Saunders, 2002). In Cheshire, salt subsidence currently affects the main railway line between Crewe and Sandbach (Figure 4), the line requires constant maintenance and has overhead power cables on adjustable gantries. The M5 motorway suffered from salt subsidence at junction 5 to the north-east of Droitwich. The construction of the new Manchester airport runway also had to consider the potential for subsidence caused by salt and dissolution breccias beneath the runway (Wilson, 2003).

\subsection{Information to inform the development of sustainable drainage systems (SUDS)}

The development of Sustainable Drainage Systems (SUDS) is being promoted in England and Wales to help mitigate the effects of flooding caused by development, which is increasing the rapidity of surface runoff (Woods-Ballard et al., 2007). In 
England and Wales, the draft Flood and Water Management Bill will include provision for the implementation of National Standards for SUDS

(Department for Environment Food and Rural Affairs, 2010). Identifying areas suitable for the safe installation of SUDS in the light of developing legislation will ensure that long-term performance is maintained while minimizing potential environmental impacts. In many areas SUDS can be effective and safe, with various solutions available including soak-aways, retention basins and porous pavements and surface materials. In some areas, the installation of infiltration based SUDS may be inappropriate. For example, disposal of surface water into the ground may lead to pollution of groundwater or increase the susceptibility to geohazards. In karst areas any water disposal method that infiltrates drainage through the ground has the potential to wash fine materials out of the covering deposits and induce sinkhole development (Figure 8). This is a well-documented phenomenon alongside US highways where drainage ditches commonly cause the development of sinkholes adjacent to the road (Fleury, 2009; Ford and Williams, 2007; Waltham et al., 2005). Sinkholes have been reported alongside some modern British roads, especially where old land drains have been cut or new drainage channels installed. Sinkholes caused by leaking pipes are well documented (McDowell, 2005; Waltham et al., 2005) and the area around Fontwell has suffered a large number of serious collapses when the local water main broke (Figure 2).

Soak-aways from surface runoff or septic tanks are a well-known anthropogenic trigger that has caused subsidence in many places (Waltham et al., 2005). Within England and Wales there are policies for groundwater protection related to foul water soakaways (Environment Agency, 2010b; Environment Alliance, 2006) and information about infiltration testing and system design (British Standards Institution, 2005; British Standards Institution, 2007). Septic tanks are not allowed in Zone 1 groundwater protection areas (which are the areas most susceptible to groundwater pollution), but the only apparent constraints are pollution prevention and suitable ground permeability assessed by percolation testing (Office of the Deputy Prime Minister, 2002). No mention is made of potential karstic ground instability problems that can result from changes in the local input of water into the ground. 


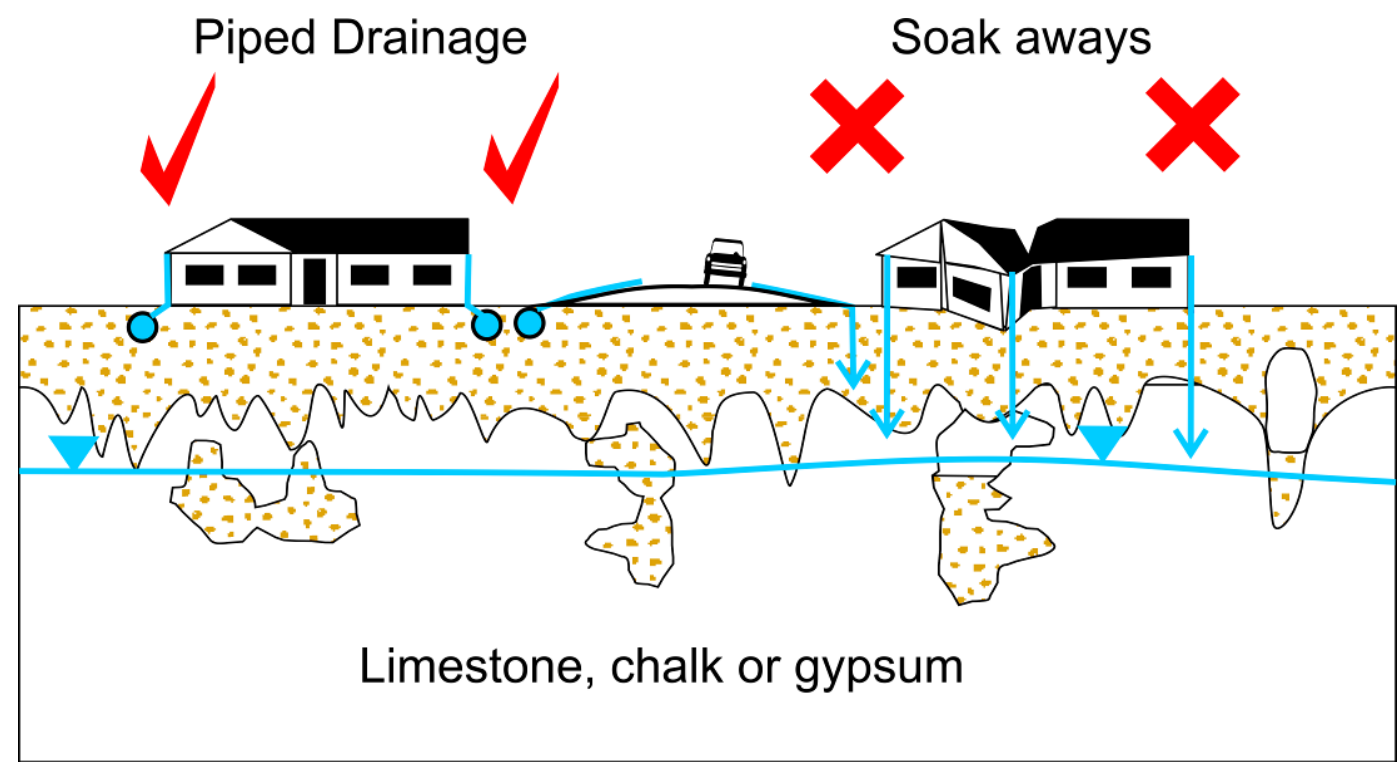

Figure 8. Disposal of surface water in karstic areas can trigger subsidence, such areas are unlikely to be suitable for SUDS that use soakaways; the groundwater potentiometric surface is marked with triangles.

Inappropriate disposal of surface and foul water can increase the susceptibility to karstic collapse. The information in the GeoSure data has the potential to be used for assessing ground suitability both for Sustainable Drainage Systems and local foul water disposal. The GeoSure data could be used to construct a decision support dataset that would inform and possibly help regulate the installation of such facilities. Some areas will be inappropriate for SUDS because of high groundwater levels and the potential for groundwater flooding, especially in the Chalk. Some areas will be inappropriate because of karst. In other areas groundwater quality may be affected, but this is dependant in part on the attenuation capacity of the geological subsurface. Conversely, some areas will be suitable for SUDS schemes where there are freedraining deposits and deep water tables, or thick clay deposits suitable for the installation of surface lagoons.

\subsection{Information to help with the safe implementation of ground source heat and cooling pumps}

Ground source heat pumps and ground cooling systems (Arthur et al., 2010; Busby et al., 2009) are becoming popular as a source of green energy or an energy efficient cooling system. However, their uncontrolled and uninformed installation could cause future problems and liabilities. The installation of open loop ground source heat pumps and open loop cooling systems in formations such as the Chalk aquifer of the London region is subject to controls by the Environment Agency with respect to groundwater source abstraction licenses and discharge consents which are granted for limited times (Fry, 2009; LeFeuvre and St John Cox, 2009). However, the development of ground source heat pumps in the Chalk of the London area have also highlighted the need to carry out the Rossum Sand Test to assess the risk of sand being transported from the Thanet Sand Formation into the wells (Chen, 2009). There is evidence of palaeo karstification and fracture enlargement at the contact between the Chalk and the overlying Thanet Sand Formation (Allen et al., 1997; Ellison, 2004) 
This leads to a further potential problem that is not addressed: that of subsidence caused by the collapse of the Thanet Sand Formation into karstic cavities in the underlying Chalk. This failure mechanism was responsible for the destruction of four houses in Bromley on the outskirts of London in April 2006; it also forced the temporary closure of a main railway line and the evacuation of 20 houses (BBC, 2006; Faber Maunsell, 2006). The exact triggering mechanism of this collapse is not known, but similar collapses in the future could be induced by the installation of open loop ground source heat pumps in this sequence. Similarly, other karstic sequences could also be affected and information needs to be made available to inform the regulators.

The GeoSure information gives an indication of the susceptibility of areas to karstic collapse and could be used to define where it would be unwise to install open loop ground source heat pump systems. In these areas there should be a presumption in favor of closed loop systems (Figure 9). This GeoSure information could be integrated with information on the ground thermal conductivity, terrestrial heat flow and other controlling factors (Busby et al., 2009) to produce a national ground source heat pump suitability map.

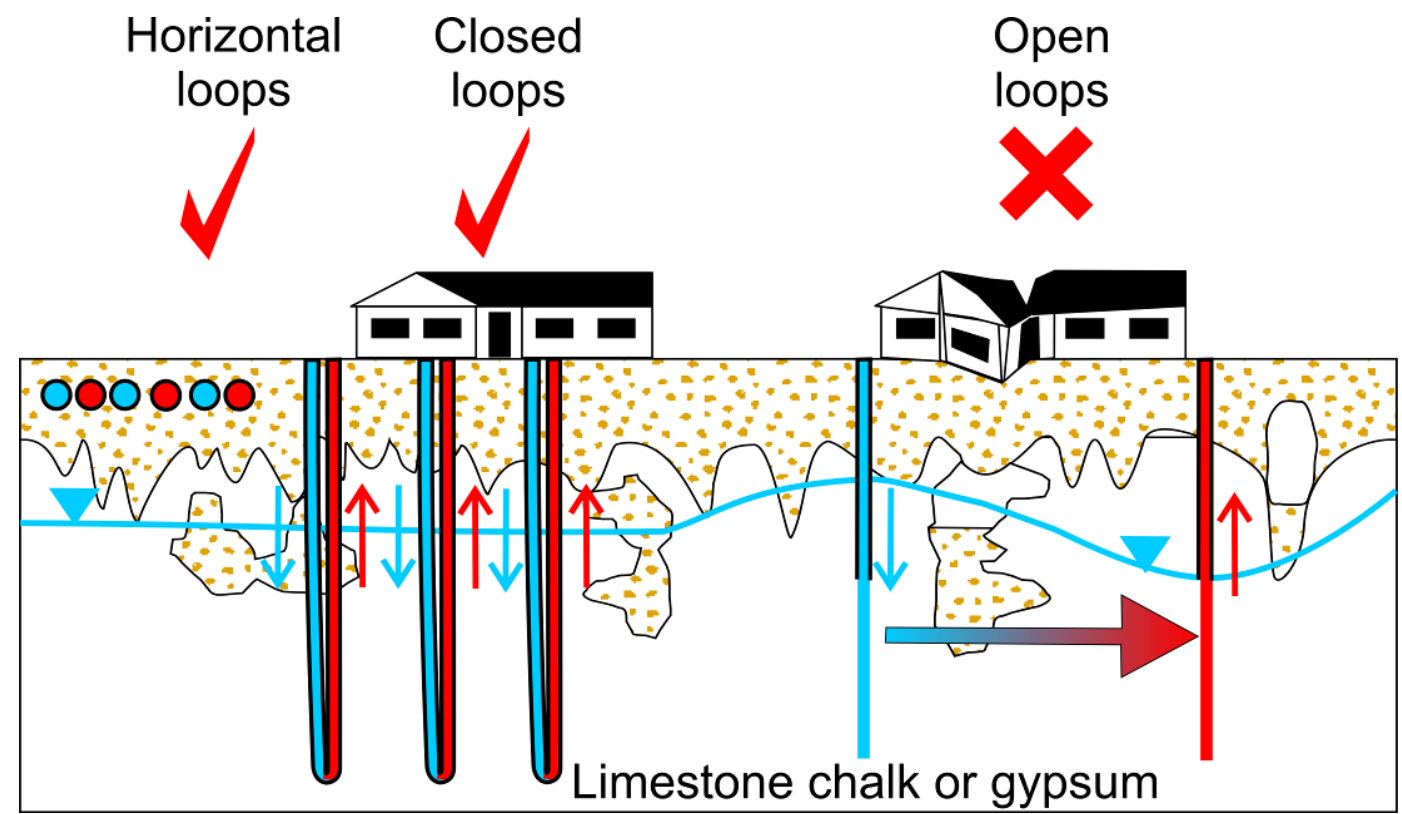

Figure 9. Subsidence problems in karst areas that could be caused by open loop ground source heat pumps (and cooling systems); closed loop systems are unlikely to cause such problems; the groundwater potentiometric surface is marked with triangles.

\subsection{Groundwater abstraction and aquifer protection}

In England and Wales the protection and licensing of ground water abstraction is managed by the Environment Agency. Based on groundwater modelling, groundwater protection zones have been defined for groundwater supplies and the information is available on the internet with an interactive searchable map "What's in your backyard?” (Environment Agency, 2010a). Groundwater protection zones benefit from regulations on the amount of fertilizers that can be applied to the ground and regulations with respect to pollutants entering the ground. For the groundwater modelling, the overall nature of the aquifers and superficial materials are taken into 
account, but the degree of karstification and details of the karst are not generally known or built in to the models. Using tracer tests, it has been shown in many limestone areas, and some chalk areas, that the presence of karstic conduits can permit the very rapid transmission of pollutants (Maurice et al., 2006). In Lithuania the presence of sinkholes is taken into account when assessing the aquifer vulnerability in karst areas and the agricultural regulation around them (Paukstys et al., 1999). Similar approaches are taken in parts of the USA (Fleury, 2009)(Table 2.1) with various setback distances ranging up to 500 feet (c. 155m), depending on the municipality. It is feasible to use the BGS GeoSure soluble rocks dataset to help directly with the modelling of the susceptibility of groundwater pollution via sinkholes in areas of karst.

All karstic areas are prone to subsidence caused by natural or induced fluctuations in the local groundwater levels. Both local groundwater recharge and abstraction can trigger subsidence. Catastrophic collapses can be triggered this way as exemplified by the problems that were caused by abstraction and irrigation in Florida (Tihansky, 1999). The effective management of karstic aquifers should include controls on the rate and range of the fluctuations in the piezometric surface and the distribution of infiltration. Large-scale abstraction for industry or irrigation can cause subsidence. Irrigation of fields is also proven to cause an increase in subsidence features in geologically susceptible areas (Gutiérrez et al., 2008). Currently in the England and Wales there is no regulation of groundwater abstraction that specifically considers the susceptibility of areas to subsidence induced in the karstic rocks. Instances of karstic collapses have occurred near groundwater abstraction sites (Cooper, 1988). The GeoSure soluble rocks dataset can be used to inform regulators in areas where ground water abstraction could cause problems.

The nature of the water emerging from various types of karst can also have a strong influence on the local use of groundwater and, in some places, the surface waters as well. Areas with salt karst and salt springs (locally called wiches (Cooper, 2002)) are obviously unsuitable for potable water supplies and provide natural excesses of chloride to surface water flows. Salt marsh floras are associated with many of these springs and chloride highs are recorded in places underlain by salt deposits such as central Cheshire (British Geological Survey, 1997). Along the outcrop of the Permian gypsum karst there are numerous artesian sulfate-rich springs, some of which rise through water-filled sinkholes, including Hell Kettles near Darlington, Hall Garth Ponds near Ripon and Askern ponds near Doncaster. Waters in these ponds have very high dissolved calcium sulfate levels, commonly with more than 1600-2000 ppm of dissolved mineral. However, not all gypsiferous groundwater is considered problematical as it is naturally 'Burtonised' (Cooper, 1988). This is a process of using naturally sulfate-rich water (originally in Burton upon Trent) for brewing beer. Water with natural or added gypsum of around $400 \mathrm{Mg} / \mathrm{l}$ is required for bitter and $100 \mathrm{Mg} / \mathrm{l}$ for porter. The gypsum enhances the bitter taste given by the hops, hence the name "bitter" used for English beer. Unfortunately, a downside of large-scale groundwater abstraction from gypsum karst is accelerated dissolution and karstification. One water supply in England using water for food processing effectively removed 200 cubic meters of dissolved gypsum per year from beneath Ripon (Cooper, 1988). 


\subsection{Linear route selection, site selection and hazard assessment}

Water, oil and gas pipelines constructed across karst areas are potential pollution sources and some may pose explosion hazards (Waltham et al., 2005). Roads and railways built across karst may suffer subsidence damage and difficult construction conditions (Cooper and Saunders, 2002; Guerrero et al., 2008), furthermore, they may also pose a potential source of pollution that could threaten karst groundwater (Price, 1994; Price et al., 1992). Existing pipeline and transport networks and new proposed routes can be assessed for their vulnerability to karst problems by using geohazard information included in the BGS GeoSure soluble rock dataset. This provides a usable indicator of the likelihood of subsidence and allows areas potentially vulnerable to subsidence or hydrogeological contamination to be delineated (Gibson et al., 2005). Combining this information with either geomorphological map data or information from the karst database helps with the routing and management of these structures. In addition to local site-specific reports, geological enquiries responded to by BGS often require information on linear routes at an early stage of the site investigation. For these reports, map and summary geohazard information from the GeoSure data are automatically downloaded and included in a report template.

\subsection{Insurance in karst areas}

Sinkhole insurance was pioneered in Florida. From 1981, Florida statute 627.706 afforded residents considerable security, although from January $1^{\text {st }} 2010$ this was downgraded in favor of the insurance companies. Within the United Kingdom, land subsidence has been included in insurance since 1971 (Waltham et al., 2005) and since 1994 the British Geological Survey has supplied insurance companies with a dataset indicating susceptibility to subsidence (Culshaw and Kelk, 1994). The subsequent GeoSure soluble rocks GIS information is used by some insurance companies to manage their exposure to liability; in some areas a small extra premium is levied. British insurance covers the damage to the property caused by subsidence including sinkhole development, but in most cases it does not include the liability related to the land. Consequently, while a property owner may be reimbursed for the cost of the buildings they can be held personally liable for the resultant collapse hole and loss of support to adjacent land (both by sinkholes and landslides) (Griffiths and Doornkamp, 1995). Where this has affected an adjacent property there have been legal cases where neighbors have claimed for physical remediation of the sinkhole and support reinstated to their property.

\section{Conclusions}

The five main types of karstic rocks (limestone, chalk, dolomite, gypsum and salt) and their associated features in Great Britain all pose environmental constraints on development and infrastructure. By defining their characteristics, their bedrock geology and that of the superficial deposits, karstic rocks can be assessed and map information derived to indicate their susceptibility to subsidence and collapse. The BGS soluble rocks dataset summarizing susceptibility to subsidence and collapse in areas of karstic rocks is marketed as part of the GeoSure suite of products. This dataset is already being used to assess areas for site characterization and infrastructure assessment purposes. In addition, it can potentially be used to aid the design or 
regulation of sustainable drainage systems (SUDS), geothermal heat pump installations and groundwater protection and abstraction. The karst dataset has the potential to become part of a suite of planning management tools for local and National Government to assess the long term sustainable use of the ground.

\section{Acknowledgements}

The authors thank Dr Helen Reeves, Dr Colm Jordan, Matt Harrison and Dr John Busby, for helpful discussions about the work and/or comments on the manuscript. The two anonymous referees are thanked for their helpful and constructive comments. The paper is published with permission of the Executive Director, British Geological Survey (NERC).

\section{Figure Captions:}

Figure 1. Soluble rock types and their distribution in the Great Britain. Based on the BGS 1:625,000 scale Bedrock Geology map of the UK, copyright BGS/NERC.

Figure 2. Seventy catastrophic dropout sinkholes caused in 1985 by a burst water main in solifluction deposits over raised beach deposits on Chalk at Littleheath Road, Fontwell, Sussex (photo (C) Sealand Aerial Photography Ltd, Chichester, reproduced under licence.)

Figure 3. Schematic cross section through the Permian gypsum sequence showing the development of caves, collapse breccia pipes and some sinkhole types in the gypsum karst.

Figure 4. Salt karst subsidence features caused both naturally and induced by dissolution related to brine extraction. National Grid (c) Ordnance Survey, used under licence number 100017897/2010

Figure 5. Schematic section through the north crop of the South Wales coalfield showing the relationships between the runoff margin, feather edge zone and Interstratal karst zone.

Figure 6. Sinkholes formed in the marginal runoff area where water from sandstones and mudstones sinks into limestones $2 \mathrm{~km}$ NW of Muker, North Yorkshire. Air photography (C) UKP/Getmapping reproduced under Licence No. UKP2006/01; Bedrock geology from BGS DiGMapGB-50.

Figure 7 Comparison of GeoSure classified areas with sinkhole distribution from the karst database for the Ripon district. The main subsidence area is underlain by gypsum, the area with low potential for subsidence is underlain by dolomite. Geology from BGS 1;50,000 scale DigMap50 bedrock geology dataset copyright BGS/NERC.

Figure 8. Disposal of surface water in karstic areas can trigger subsidence, such areas are unlikely to be suitable for SUDS that use soakaways; the groundwater potentiometric surface is marked with a triangle.

Figure 9. Subsidence problems in karst areas that could be caused by open loop ground source heat pumps (and cooling systems); closed loop systems are unlikely to cause such problems; the groundwater potentiometric surface is marked with a triangle. 


\section{References}

Allen, D.J., Brewerton, I.J., Coleby, L.M., Gibbs, B.R., Lewis, M.A., MacDonald, A.M., Wagstaff, S.J., Williams, A.T., 1997. The physical properties of major aquifers in England and Wales, Technical Report WD/97/34, Environment Agency R\&D Publication 8, British Geological Survey.

Applied Geology Limited, 1993. Review of instability due to natural underground cavities in Great Britain. Applied Geology Ltd, Royal Lemington Spa.

Arthur, S., Streetley, H.R., Valley, S., Streetley, M.J., Herbert, A.W., 2010. Modelling large ground source cooling systems in the Chalk aquifer of central London. Quarterly Journal of Engineering Geology and Hydrogeology, 43, 289-306.

Banks, D., Davies, C., Davies, W., 1995. The Chalk as a karstic aquifer: evidence from a tracer test at Stanford Dingley, Berkshire, UK. Quarterly Journal of Engineering Geology, 28, S31-S38.

BBC, 2006. More homes razed after collapse, April 2006 http://news.bbc.co.uk/1/hi/england/london/4915618.stm accessed 22nd March 2011.

Brinkmann, R., Parise, M., Dye, D., 2008. Sinkhole distribution in a rapidly developing urban environment: Hillsborough County, Tampa Bay area, Florida. Engineering Geology, 99, 169-184.

British Geological Survey, 1997. Regional geochemistry of parts of north-west England and North Wales. British Geological Survey, Keyworth, Nottingham.

British Geological Survey, 2010a. Geological Data Index (GeoIndex) http://www.bgs.ac.uk/GeoIndex/ accessed 22nd March 2011

British Geological Survey, 2010b. Rock Classification Scheme http://www.bgs.ac.uk/bgsrcs/ accessed 22nd March 2011.

British Standards Institution, 2005. BS EN 12566-3:2005+A1:2009, Small wastewater treatment systems for up to 50PT. Packaged and/or site assemble domestic wastewater treatment plants.

British Standards Institution, 2007. BS 6297:2007+A1:2008, Code of practice for the design and installation of drainage fields for use in wastewater treatment.

Busby, J., Lewis, M., Reeves, H., Lawley, R.S., 2009. Initial geological considerations before installing ground source heat pump systems. Quarterly Journal of Engineering Geology and Hydrogeology, 42(3), 295-306.

Chen, A., 2009. Running Hot and Cold: Report of the joint meeting of the British Geotechnical Association and the Engineering Group of the Geological Society on ground source energy systems, Wednesday 11 February 2009. Ground Engineering(August 2009), 10-11.

Cooper, A.H., 1986. Foundered strata and subsidence resulting from the dissolution of Permian gypsum in the Ripon and Bedale areas, North Yorkshire. In: G. Harwood, D.B. Smith (Eds.), The English Zechstein and related topics. Geological Society of London, Special Publication No. 22, pp. 127-139.

Cooper, A.H., 1988. Subsidence resulting from the dissolution of Permian gypsum in the Ripon area; its relevance to mining and water abstraction. In: F.G. Bell, M.G. Culshaw, J.C. Cripps, M.A. Lovell (Eds.), Engineering Geology of Underground Movements. Geological Society of London, Engineering Geology Special Publication No. 5, pp. 387-390.

Cooper, A.H., 1989. Airborne multispectral scanning of subsidence caused by Permian gypsum dissolution at Ripon, North Yorkshire. Quarterly Journal of Engineering Geology, 22(3), 219-229. 
Cooper, A.H., 1998. Subsidence hazards caused by the dissolution of Permian gypsum in England: geology, investigation and remediation. In: J.G. Maund, M. Eddleston (Eds.), Geohazards in Engineering Geology. Geological Society, London, Engineering Geology Special Publication 15, pp. 265-275.

Cooper, A.H., 2002. Halite karst geohazards (natural and man-made) in the United Kingdom. Environmental Geology, 42(5), 505-512.

Cooper, A.H., 2008a. The classification, recording, databasing and use of information about building damage caused by subsidence and landslides. Quarterly Journal of Engineering Geology and Hydrogeology, 41(3), 409-424.

Cooper, A.H., 2008b. The GIS approach to evaporite karst geohazards in Great Britain. Environmental Geology, 53(5), 981-992.

Cooper, A.H., Calow, R., 1998. Avoiding gypsum geohazards: guidance for planning and construction, British Geological Survey Technical Report, WC/98/5.

Cooper, A.H., Farrant, A.R., Adlam, K.A.M., Walsby, J.C., 2001. The development of a national Geographic Information System (GIS) for British karst geohazards and risk assessment. In: B.F. Beck, J.G. Herring (Eds.), Geotechnical and Environmental Applications of Karst Geology and Hydrology. Balkema, pp. 125-130.

Cooper, A.H., Saunders, J.M., 2002. Road and bridge construction across gypsum karst in England. Engineering Geology, 65(2-3), 217-223.

Culshaw, M.G., Kelk, B., 1994. A national geo-hazard information system for the UK insurance industry - the development of a commerical product in a geological survey environment: Paper 111, Proceeding 1st European Congress on Regional Geological Cartograpy and Information Systems, Bologna, Italy, pp. 3.

Department for Environment Food and Rural Affairs, 2010. Flood and Water Management Bill.

Department of the Environment, 1990. Planning policy guidance note 14: Development on unstable land. HMSO London.

Department of Transport Local Government and the Regions, 2002. Planning policy guidance note 14. Development on unstable land. Annex2: Subsidence and planning. The Stationary Office, London.

Edmonds, C.N., 1983. Towards the prediction of subsidence risk upon the Chalk outcrop. Quarterly Journal of Engineering Geology, 16, 261-266.

Edmonds, C.N., 2001a. Predicting natural cavities in chalk. In: J.S. Griffiths (Ed.), Land Surface Evaluation for Engineering Practice. Engineering Geology Special Publications, 18. The Geological Society of London, pp. 29-38.

Edmonds, C.N., 2001b. Subsidence hazard in Berkshire in areas underlain by chalk karst. In: J.S. Griffiths (Ed.), Land Surface Evaluation for Engineering Practice. Engineering Geology Special Publications, 18. The Geological Society of London, pp. 97-106.

Edmonds, C.N., 2008. Karst and mining geohazards with particular reference to the Chalk outcrop, England. Quarterly Journal of Engineering Geology and Hydrogeology, 41, 261-274.

Edmonds, C.N., Green, C.P., Higginbottom, I.E., 1987. Subsidence hazard prediction for limestone trerrains, as applied to the English Cretaceous Chalk. In: M.G. Culshaw, F.G. Bell, J.C. Cripps, M. O'Hara (Eds.), Planning and Engineering Geology, Engineering Geology Speical Publication, 4. Geological Society, pp. 283-293. 
Edmonds, C.N., Martin, G., Marker, B.R., 1989. A national study of natural underground cavities in Great Britain - Data collection, spatial analysis, planning and engineering significance. In: B.F. Beck (Ed.), Engineering and Environmental Impacts of Sinkholes and Karst: Third multidisciplinary conference on sinkholes and the engineering and environmental impacts of karst, St.Petersburg Beach, Florida, 2-4 October 1989. Balkema, Rotterdam, pp. 349-359.

Ellison, R.A., 2004. Geology of London. British Geological Survey.

Environment Agency, 2010a. Groundwater protection zones http://www.environmentagency.gov.uk/homeandleisure/37833.aspx accessed 22nd March 2011.

Environment Agency, 2010b. Groundwater protection: Policy and practice (GP3 Part 4) http://publications.environment-agency.gov.uk/pdf/GEHO0708BOGUe-e.pdf accessed 22nd March 2011.

Environment Alliance, 2006. Pollution prevention guidelines: Treatment and disposal of dewage where no foul sewer is available: PPG4. Environment Agency.

European Parliament, 2000. Directive 2000/60/EC of the European Parliament and of the Council of 23 October 2000 establishing a framework for Community action in the field of water policy. Official Journal of the European Communities, pp. L327/321 - L327/372.

European Parliament, 2006. Directive 2006/118/EC of the European Parliament and of the Council of 12 December 2006 on the protection of groundwater against pollution and deterioration. Official Journal of the European Union, pp. L372/319 - L372/331.

Faber Maunsell, 2006. Highway Structures General Advice - Ridley Road Emergency Works Final Report on Site Investigations. For London Borough of Bromley Environmental Services Department $5^{\text {th }}$ December 2006 <http://www.bromley.gov.uk/NR/rdonlyres/77FB058D-886B-443F-9AC7C190741CC679/0/RidleyRoadfinalreport.pdf $>$ accessed 22nd March 2011.

Farrant, A.R., 2001. Karst development in the southern English Chalk. In: B.F. Beck, J.G. Herring (Eds.), Geotechnical and environmental applications of karst geology and hydrogeology. Proceedings of the eighth Multidisciplinary Conference on Sinkholes and the Engineering and Environmental Impacts of Karst, April 1-4th Louisville, Kentucky, USA. Balkema, pp. 77-82.

Farrant, A.R., Cooper, A.H., 2008. Karst geohazards in the UK: the use of digital data for hazard management. Quarterly Journal of Engineering Geology and Hydrogeology, 41, 339-356.

Fleury, S., 2009. Land Use Policy and Practice on Karst Terrains - Living on Limestone. Springer.

Ford, D., Williams, P., 2007. Karst hydrogeology and geomorphology. John Wiley and Sons Ltd, Chichester, England.

Fry, V.A., 2009. Lessons from London: regulation of open-loop ground source heat pumps in central London. Quarterly Journal of Engineering Geology and Hydrogeology, 42(3), 325-334.

Galve, J.P., Gutiérrez, F., Remondo, J., Bonachea, J., Lucha, P., Cendrero, A., 2009. Evaluating and comparing methods of sinkhole susceptibility mapping in teh Ebro Valley evaporite karst (NE Spain). Geomorphology, 111, 160-172.

Gibson, A.D., Forster, A., Culshaw, M.G., Cooper, A.H., Farrant, A.R., Jackson, N., Willet, D., 2005. Rapid geohazard assessment system for the UK Natural Gas Pipeline Network, Geoline 2005 : International Symposium on Geology and Linear Developments, 23rd-25th May 2005, Lyon, France. 
Government Draft Statutory Instruments, 2009. The Groundwater (England and Wales) Regulations 2009. Her Majesty's Stationary Office, pp. 1-10.

Griffiths, J.S., Doornkamp, J.C., 1995. Land instability and the legal responsibilities of the landowner, developer and consultant earth scientist. Terra Nova, 7(550503).

Guerrero, J., Gutiérrez, F., Bonachea, J., Lucha, P., 2008. A sinkhole susceptibility zonation based on paleokarst analysis along a stretch of the Madrid-Barcelona high-speed railway built over gypsum- and salt-bearing evaporites (NE Spain). Engineering Geology, 102, 62-73.

Gutiérrez, F., Cooper, A.H., 2002. Evaporite dissolution subsidence in the historical city of Calatayud, Spain: Damage appraisal and prevention. Natural Hazards, 25(3), 259-288.

Gutiérrez, F., Cooper, A.H., Johnson, K.S., 2008. Identification, prediction, and mitigation of sinkhole hazards in evaporite karst areas. Environmental Geology, 53(5), 1007-1022.

Gutiérrez, F., Galve, J.P., Luch, P., Bonachea, J., Jordá, L., Jordá, R., 2009. Investigation of a large collapse sinkhole affecting a multi-storey building by means of geophysics and the trenching technique (Zaragoza city, NE Spain). Environmental Geology, 58, 1107-1122.

Hall, M., Cooper, A.H., Ford, J.R., Price, S.J., Burke, H., 2010. The use of NEXTMap Britain for geological surveying in the Vale of York. In: C. Fleming, J.R.A. Giles, S.H. Marsh (Eds.), Elevation models in Geoscience. Special Publication of the Geological Society 345, pp. 55-66.

Harrison, M., Forster, A., 2006. The Assessment of National Scale Geohazard potential through the application of GIS modelling. In: M.G. Culshaw, H. Reeves, I. Jefferson, T.W. Spink (Eds.), Engineering Geology for Tomorrow's Cities. The Geological Society, London, pp. CD paper number 286.

Howard Humphreys and Partners Ltd, 1993. Subsidence in Norwich. Report of the study on the causes and mechanisms of landsubsidence, Norwich, carried out for the Department of the Environment (Research conract PECD7/1/362). HMSO, London.

James, A.N., 1992. Soluble Materials in Civil Engineering. Ellis Horwood, Chichester.

James, A.N., Cooper, A.H., Holliday, D.W., 1981. Solution of the gypsum cliff (Permian Middle Marl) by the River Ure at Ripon Parks, North Yorkshire. Proceedings of the Yorkshire Geological Society, 43(4), 433-450.

Klimchouk, A., 1996. The dissolution and conversion of gypsum and anhydrite. In: A. Klimchouk, Lowe, D, Cooper, A and Sauro, U (Ed.), Gypsum karst of the world. International Journal of Speleology Vol. 25, pp. 9-20.

Klimchouk, A., Cucchi, F., Calaforra, J.M., Aksem, S., Finocchiaro, F., Forti, P., 1996. The dissolution of gypsum from field observations. In: A. Klimchouk, D. Lowe, A. Cooper, U. Sauro (Eds.), Gypsum karst of the world. International Journal of Speleology Vol.25, pp. 37-48.

Lamont-Black, J., Younger, P.L., Forth, R.A., Cooper, A.H., Bonniface, J.P., 2002. A decision-logic framework for investigating subsidence problems potentially attributable to gypsum karstification. Engineering Geology, 65(2-3), 205-215.

LeFeuvre, P., St John Cox, C., 2009. Evidence. Ground source heating and cooling pumps - state of play and future trends, Environment Agency report prepared by AEA Technology Plc. 
Maurice, L.D., Atkinson, T.C., Barker, J.A., Bloomfield, J.P., Farrant, A.R., Williams, A.T., 2006. Karstic behaviour of groundwater in the English Chalk. Journal of Hydrology, 330, 63-70.

McDowell, P.W., 2005. Geophysical investigations of sinkholes in chalk, U.K. Case Study No 9. In: A.C. Waltham, F.G. Bell, M.G. Culshaw (Eds.), Sinkholes and Subsidence. Karst and Cavernous Rocks in Engineering and Construction. Praxis, Chichester, pp. 313-316.

McDowell, P.W., Coulton, J., Edmonds, C.N., Poulsom, A.J., 2008. The nature, formation and engineering significance of sinkholes related to dissolution of chalk in SE Hampshire, England. Quarterly Journal of Engineering Geology and Hydrogeology, 41(3), 279-290.

Murphy, P.J., 2000. The karstification of the Permian strata east of Leeds. Proceedings of the Yorkshire Geological Society, 53, 25-30.

Office of the Deputy Prime Minister, 2002. The Building Regulations 2000; section $\mathrm{H}$ : Drainage and waste disposal http://www.planningportal.gov.uk/uploads/br/BR_PDF_ADH_2002.pdf accessed 22nd March 2011.

Patterson, D.A., Davey, J.C., Cooper, A.H., Ferris, J.K., 1995. The investigation of dissolution subsidence incorporating microgravity geophysics at Ripon, Yorkshire. Quarterly Journal of Engineering Geology, 28, 83-94.

Paukstys, B., Cooper, A.H., Arustiene, J., 1999. Planning for gypsum geohazards in Lithuania and England. Engineering Geology, 52(1-2), 93-103.

Price, M., 1994. Drainage from roads and airfields to soakways: groundwater pollutant or valuable recharge? Journal of the Institution of Water and Environmental Management 8(5), 468-479.

Price, M., Atkinson, T.C., Barker, J.A., Wheeler, D., Monkhouse, R.A., 1992. A tracer study of the danger posed to a chalk aquifer by contaminated highway run-off. Proceedings of the Institution of Civil Engineers Water, Maritime \& Energy, 96(Paper 9754), 9-18.

Reuter, F., Tolmachev, V.V., Molek, H., Suderlau, G., Chomenko, V.P., 1990. Bauen und Bergbau in Senkungs- und Erdfallgebieten, Eine Ingenieurgeologie des Karstes. Schriftenreihe für Geologische Wissenschaften, Academie-Verlag, Berlin, 28.

Sargent, C., Goulty, N.R., 2009. Seismic reflection survey for investigation of gypsum dissolution and subsidence at Hell Kettles, Darlington, UK. Quarterly Journal of Engineering Geology and Hydrogeology, 42, 31-38.

Smith, D.B., 1989. The late Permian palaeogeography of north-east England. Proceedings of the Yorkshire Geological Society, 47(4), 285-312.

Sowers, G.F., 1996. Building on Sinkholes - Design and Construction of Foundations in Karst Terrain. American Society of Civil Engineers New York.

Thompson, A., Hine, P.D., Greig, J.R., Peach, D.W., 1996. Assessment of subsidence arising from gypsum dissolution, Symonds Group Ltd, East Grinstead.

Thompson, A., Hine, P.D., Peach, D.W., Frost, L., Brook, D., 1998. Subsidence Hazard Assessment as a basis for Planning Guidance in Ripon. In: J.G. Maund, M. Eddleston (Eds.), Geohazards in Engineering Geology. Geological Society, London, Engineering Geology Special Publication 15, pp. 415-426.

Tihansky, A.B., 1999. Sinkholes, West-Central Florida. In: D. Galloway, D.R. Jones, S.E. Ingebritsen (Eds.), Land Subsidence in the United States. USGS Circular 1182. 
Tuckwell, G., Grossey, T., Owen, S., Stearns, P., 2008. The use of microgravity to detect small distributed voids and low-density ground. Quarterly Journal of Engineering Geology and Hydrogeology, 41, 371-380.

Waltham, A.C., Bell, F.G., Culshaw, M.G., 2005. Sinkholes and Subsidence; Karst and cavernous rocks in engineering and construction. Praxis, Springer, Chichester, UK.

Waltham, A.C., Cooper, A.H., 1998. Features of gypsum caves and karst at Pinega (Russia) and Ripon (England). Cave and Karst Science, 25(3), 131-140.

Waltham, A.C., Simms, M.J., Farrant, A.R., Goldie, H., 1997. Karst and Caves of Great Britain. Conservation Review Series. Chapman and Hall, London.

Wilson, A.A., 2003. The Mercia Mudstone Group (Triassic) of Manchester Airport, Second Runway. Proceedings of the Yorkshire Geological Society, 54(3), 129145.

Woods-Ballard, B., Kellagher, R., Martin, P., Jeffries, C., Bray, R., Shaffer, P., 2007. The SUDS Manual, C697. CIRIA, London. 